Jurnal Health Sains: p-ISSN: 2723-4339 e-ISSN: 2548-1398

Vol. 2, No. 4, April 2021

\title{
MENGKAJI PENGARUH PEMBERIAN LEMON TEHADAP EMESIS GRAVIDARUM
}

\section{Is Susiloningtyas dan Siti Suhartinah}

Universitas Islam Sultan Agung, Semarang, Jawa Tengah, Indonesia

Email: susiloningtyas@unissula.ac.id dan sitisuhartinah01@gmail.com

\begin{tabular}{ll}
\hline ARTIKEL INFO & ABSTRACT \\
\hline Tanggal diterima: 5 April 2021 & During pregnancy, various changes occur both physical \\
Tanggal revisi: 15 April 2021 & and psychic changes that allow problems to occur in \\
Tanggal yang disetujui: 25 & pregnancy, especially first trimester pregnancy. The method \\
April 2021 & offoreign literature is traced through electronic media with \\
\hline Keywords: & keyword guide. The articles selected a number of 8 , each of \\
aromatherapy; lemon; emesis & which represents one effect of lemon on the decrease in \\
gravidarum & vomiting nausea in pregnant women and provides varied \\
& information. The results showed a difference in vomiting \\
& nausea in respondents before and after treatment with \\
& lemon aromatherapy. How to overcome vomiting nausea \\
& during pregnancy can be done in several ways that can be \\
& through pharmacological and non-pharmacological \\
& measures. Non-pharmacological measures are usually \\
& recommended by health officials such as encouraging \\
& pregnant women to perform aromatherapy. One of the \\
& aromatherapy that can be used to reduce vomiting nausea \\
& while pregnant is lemon aromatherapy because lemon has \\
& ingredients that can kill meningococcus bacteria \\
(meningococcus), typhus bacteria, has an antifungal effect \\
and is effective to neutralize unpleasant odors, as well as \\
produce anti-stress, antidepressants, anti-stress, as well as \\
to lift and focus the mind. The conclusion of the study is \\
based on analysis that has been done, the use of lemon \\
aromatherapy is effective to reduce vomiting nausea in \\
pregnantwomen.
\end{tabular}

\begin{abstract}
ABSTRAK
Selama masa kehamilan, berbagai perubahan terjadi baik perubahan fisik maupun psikis yang memungkinkan timbulnya masalah pada kehamilan, terutama kehamilan trimester pertama. Metode literatur mancanegara ditelusuri melalui sarana media elektronik dengan penuntun kata kunci. Artikel terseleksi sejumlah 8, yang masing masing mewakili satu pengaruh lemon terhadap penurunan mual muntah pada ibu hamil dan memberi informasi yang bervariatif. Hasilnya menunjukan adanya perbedaan mual muntah pada responden sebelum dan sesudah dilakukan pemberian perlakuan dengan aromaterapi lemon. Cara mengatasi mual muntah pada saat hamil dapat dilakukan dengan beberapa cara yaitu dapat melalui tindakan farmakologis dan non farmakologis. Tindakan non
\end{abstract}

Susiloningtyas, Is, et. al. (2021) Mengkaji Pengaruh Pemberian Lemon Tehadap Emesis Gravidarum. Jurnal Health Sains 2(4).

http://jurnal.healthsains.co.id/index.php/jhs/article/view/141

2723-6927

Ridwan Institute 
Kata Kunci:

aromaterapi; lemon; emesis gravidarum farmakologis biasanya dianjurkan oleh petugas kesehatan seperti mendorong ibu hamil untuk melakukan aromaterapi. Salah satu aromaterapi yang dapat digunakan untuk mengurangi mual muntah saat hamil yaitu aromaterapi lemon karena lemon memiliki bahan yang dapat membunuh bakteri meningokokus (meningococcus), bakteri tifus, memiliki efek antijamur dan efektif untuk menetralkan bau tidak sedap, serta menghasilkan anticemas, antidepresi, anti stres, serta untuk mengangkat dan memfokuskan pikiran. Kesimpulan penelitian yaitu berdasarkan analisa yang telah dilakukan, penggunaan aromaterapi lemon efektif untuk mengurangi mual muntah pada ibu hamil.

\section{Pendahuluan}

Kehamilan merupakan hubungan yang berkelanjutan, terdiri dari ovulasi, migrasi spermatozoa dan ovum, pembuahan dan pertumbuhan zigot, nidasi (implantasi) di dalam rahim, pembentukan plasenta dan perkembangan hasil pembuahan sampai masa penuh (Manuaba , 2010). Emesis Gravidarum merupakan gejala yang alami dan sering terjadi pada ibu hamil dimana ibu hamil akan mengalami morning sickness hampir setiap pagi dan sore hari. Gejala ini biasanya terjadi sekitar minggu ke 6 sejak hari pertama hari menstruasi terakhir sampai dengan minggu ke 12 kehamilan meskipun gejalanya mungkin tetap sampai minggu ke 20 pada beberapa wanita.

Di Indonesia, ibu hamil yang mengalami hiperemesis gravidarum mencapai $14,8 \%$ dari seluruh kehamilan yaitu $60-80 \%$ pada primigravida dan $40-60 \%$ pada multigravida. Separuh dari wanita hamil biasanya menderita mual dan muntah dan $25 \%$ hanya menderita mual. Mual dan muntah yang parah disertai gejala termasuk dehidrasi, asidosis, alkalosis, dan penurunan berat badan dapat mengancam kesehatan ibu.

Penyebab utama dari masalah ini dapat disebabkan oleh beberapa faktor salah satunya yang memiliki peran paling penting dalam masalah ini yaitu perubahan hormonal yang terjadi pada ibu hamil. Hormon yang dimaksud yaitu peningkatan hormon estrogen dan Human Chorionik Gonadrotropin (HCG) yang jika tidak segera ditangani akan berlanjut pada hyperemesis gravidarum. Meski mual dan muntah kehamilan (NVP) terbatas pada trimester pertama kehamilan, tetapi pada sebagian orang ada yang terus berlanjut berlanjut sampai persalinan walaupun dalam presentase yang kecil. Mual dan muntah yang terus menerus dapat menyebabkan cairan tubuh berkurang, sehingga darah menjadi kental (hemokonsentrasi) dan sirkulasi darah ke jaringan terlambat. Hal ini dapat mengakibatkan terjadinya kerusakan jaringan yang dapat mengganggu kesehatan ibu serta perkembangan pada janin.

Penanganan mual muntah tergantung pada tingkat keparahan gejala yang dirasakan. Pengobatan dapat menggunakan terapi farmakologis maupun non farmakologis. Terapi farmakologis dapat dilakukan dengan cara pemberian antiemetik, antihistamin, antikolinergik dan kortikosteroid. Sedangkan terapi non farmakologis dapat dilakukan dengan cara pengaturan diet, dukungan emosional, akupunktur, perubahan pola hidup, istirahat, tidur dan dengan pemberian pengobatan herbal/ alamiah seperti jahe maupun peppermint (Runiari, 2010). Penanganan emesis gravidarum menurut (Rinata \& Ardillah, 2017) dengan menggunakan terapi farmakologis sudah tepat namun sebagian besar belum tepat dalam melakukan pengobatan herbal/ alamiah. Salah satu alternatif untuk mengatasi mual muntah 
dalam kehamilan secara non farmakologis adalah dengan menggunakan aromaterapi.

Aromaterapi adalah minyak tumbuhan wangi yang memiliki konsentrasi tinggi dan rentan terhadap penguapan (Mulyono et al., 2018). Prinsip utama dari aromaterapi yaitu penggunaan bau dari tumbuhan atau bunga untuk merubah kondisi perasaan, psikologi, status spiritual dan mempengaruhi kondisi fisik seseorang melalui hubungan antara pikiran dan tubuh pasien. Aroma terapi lemon memiliki bahan yang dapat membunuh bakteri meningokokus (meningococcus), bakteri tifus, memiliki efek antijamur dan efektif untuk menetralkan bau tidak sedap, serta menghasilkan anticemas, antidepresi, anti stres, serta untuk mengangkat dan memfokuskan pikiran. Aromaterapi memberikan berbagai efek untuk inhaler, seperti ketenangan, kesegaran, bahkan bisa membantu ibu hamil mengatasi mual. Minyak esensial aromaterapi dapat mengatasi keluhan fisik dan psikis. Beberapa jenis minyak essensial dapat digunakan sebagai aromaterapi, antara lain peppermint, spearmint, lemon dan jahe. Tujuan penelitian ini yaitu untuk mengetahui apakah ada pengaruh konsumsi jahe terhadap penurunan rasa nyeri dismenorea pada remaja.

\section{Metode Penelitian}

Dalam penelitian ini dilakukan pencarian literatur melalui media elektronik yaitu, Pubmed, Google Scholar, Proquest. Tujuan dari artikel ini adalah yang mengulas masalah emesis gravidarum. Kata kunci yang dipakai untuk penelusuran literatur yaitu "aromatherapy lemon" "emesis gravidarum". Cara yang digunakan dalam mencari artikel menggunakan bahasa Inggris dan Indonesia yang relevan dengan topik yang dibahas. Artikel yang diperoleh yang sesuai dengan kriteria yaitu terdapat 8 artikel yang terdiri dari 5 artikel internasional dan 3 artikel nasional yang selanjutnya akan di review.

\section{Hasil dan Pembahasan}

Dari hasil literature review yang telah dipaparkan, didapatkan hasil adanya pengaruh pemberian aromaterapi lemon terhadap emesis gravidarum.

Menurut teori (Maternity, 2017) dapat disimpulkan bahwa pengurangan mual muntah pada ibu hamil trimester 1 dipengaruhi oleh beberapa faktor yaitu ibu dengan usia tidak resiko tinggi, ibu dengan kehamilan multi gravida, dan penghasilan dengan kategori sedang.

Penurunan rata-rata skor frekuensi mual muntah dengan aromaterapi lemon disebabkan karena baunya yang segar dan membantu memperbaiki atau menjaga kesehatan, membangkutkan semangat, gairah, menyegarkan serta menenangkan jiwa, dan merangsang proses penyembuhan. Ketika minyak Inhalasi lemon essensial dihirup, molekul masuk ke rongga hidung dan merangsang sistem limbik di otak. Sistem linbik adalah daerah yang mempengaruhi emosi dan memori serta secara langsung terkait dengan adrenal, kelenjar hiposis, hipotalamus, bagian-bagian tubuh yang mengatur denyut jantung, tekanan darah, stress, memori, keseimbangan hormon, dan pernafasan. Sehingga aromaterapi lemon baik untuk mengurangi mual muntah. Ada pengaruh pemberian inhalasi lemon untuk mengurangi mual muntah pada ibu hamil trimester 1 di BPS Lia Maria Sukarame Bandar Lampung Tahun 2017 dengan p-value $=0.000$ (Maternity, 2017).

Hasil penelitian ini sejalan dengan penelitian yang dilakukan oleh (Maesaroh \& Putri, 2019) didapatkan bahwa frekuensi ratarata morning sickness sebelum intervensi adalah 17,37 kali, sedangkan setelah intervensi menurun menjadi 12,43 kali. Diketahui juga ada pengaruh inhalasi aromaterapi jeruk lemon terhadap morning sickness ibu hamil trimester I ( $\mathrm{p}$ value 0,000 ). Hasil yang sama didapatkan oleh (Vitrianingsih \& Khadijah, 2019) dimana 
berdasarkan rhodes index skor morning sickness pada ibu hamil dengan emesis gravidarum sebesar 22,1 dan terjadi penurunan skor setelah dilakukan intervensi menjadi 19,8. Didapatkan bahwa aromaterapi jeruk lemon menurunkan mual di pagi hari pada ibu hamil (pvalue $=0,017$ ). Hasil penelitian ini juga sejalan dengan penelitian yang dilakukan oleh (Maternity, 2017) bahwa frekuensi morning sickness sebelum menghirup aromaterapi jeruk lemon adalah 24,67, sedangkan setelah intervensi menjadi 17,87. Dengan demikian, terdapat pengaruh inhalasi aromaterapi jeruk nipis terhadap morning sickness ibu hamil dengan nilai $\mathrm{p}=$ 0,000 (Carolin et al., 2020).

Akupresur dan aromaterapi merupakan salah satu terapi non farmakologis jenis terapi keperawatan komplementer yang dapat digunakan sebagai intervensi untuk mengatasi mual dan muntah. Aromaterapi, yang merupakan cabang dari ilmu herbal, adalah kumpulan metode penggunaan minyak esensial yang terampil dan terkontrol untuk meningkatkan kesehatan fisik, emosional, dan psikologis. Aromaterapi dapat digunakan oleh ibu hamil untuk mengurangi rasa mual, muntah, dan koping. Hasil analisis statistik menunjukkan penurunan mual pada kelompok yang diberikan akupresur dan akupresur+aromaterapi (Maghfirah et al., 2020).

Berdasarkan hasil penelitian rata-rata penurunan frekuensi mual muntah akibat aromaterapi lemon suangi mampu menurunkan frekuensi mual dan muntah pada ibu hamil yang mengalami mual muntah karena baunya yang segar serta membantu memperbaiki atau memelihara menyehatkan, membuat semangat, semangat, menyegarkan dan menenangkan jiwa, serta merangsang proses penyembuhan. Saat aroma lemon suangi terhirup, molekulnya masuk ke rongga hidung dan menstimulasi sistem limbik di otak. Sistem fisik adalah area yang mempengaruhi emosi dan ingatan dan berhubungan langsung dengan adrenal, kelenjar hiposis, hipotalamus, bagian tubuh yang mengatur detak jantung, tekanan darah, stres, ingatan, keseimbangan hormonal, dan pernapasan. Jadi aromaterapi lemon bagus untuk mengurangi mual-muntah (Purwandari et al., 2019).

Rata-rata ibu hamil yang mengalami emesis gravidarum sebelum diberikannya aromaterapi lemon yaitu sebanyak 4, 50 dan setelah diberi aromaterapi lemon berkurang menjadi 1,76. Berdasarkan sampel berpasangan uji $\mathrm{T}$-Test menunjukkan hasil $\mathrm{p}$ $=0,000$ (p-value < 0,05). Hasil ini menunjukkan bahwa ada pengaruh aromaterapi lemon tea terhadap penurunan nilai rata-rata emesis gravidarum pada ibu primigravida trimester I. Penelitian ini sejalan dengan penelitian yang dilakukan oleh Sherly et al pada tahun 2016 melakukan penelitian terhadap efek aromaterapi lemon pada intensitas mual dan muntah pada pasien dengan gagal ginjal kronis menjalani hemodialisis (Oktavia et al., 2018).

Hasil penelitian yang dilakukan oleh Rofi'ah, 2019 sejalan dengan penelitian yang dilakukan oleh (Safajou et al., 2014) yaitu hasil penelitiannya menunjukkan $40 \%$ wanita telah menggunakan aroma lemon dalam meredakan keluhan mual dan muntah. Dari sekian tersebut 26,5\% melaporkan bahwa aroma lemon merupakan cara yang efektif untuk mengontrol gejala mual muntah.

Aromaterapi lemon efektif menurunkan mual muntah pada ibu hamil trimester I (Cholifah \& Nuriyanah, 2019). Aromaterapi lemon berasal dari ekstraksi kulit jeruk lemon (Citrus Lemon) merupakan salah satu jenis aromaterapi yang aman untuk kehamilan dan melahirkan (Medforth et al., 2013). Pada penelitian ini seluruh responden menyukai bau dari aromaterapi lemon. Minyak essensial lemon mengandung limonene 66-80\%, geranil asetat, nerol, linalil asetat, $\beta$ pinene $0,4-15 \%$, $\alpha$ pinene $1-4 \%$, terpinene $6-14 \%$ dan myrcen (Young, 2011). Senyawa kimia 
seperti geranil asetat, nerol, linalil asetat, memiliki efek antidepresi, antiseptik, antispasmodik, penambah gairah seksual dan obat penenang ringan (Namazi et al., 2014).

Artikel Penelitian yang diteliti oleh (Carolin et al., 2020) yang berjudul "The Effect of Citrus lemon Aromatherapy on Emesis Gravidarum Patient". Penelitian ini menggunakan kuasi eksperimental melalui One Group Pretest-Posttest Design. Sampel diambil dengan total sampling yaitu $30 \mathrm{ibu}$ hamil trimester pertama mengalami mual. Alat ukur yang digunakan dalam penelitian ini adalah PUQE. Uji normalitas penelitian ini dilakukan dengan menggunakan nilai skewness dan kurtosis yang hasilnya berdistribusi normal sehingga uji statistik yang digunakan adalah Paired Ttest. Bahan yang digunakan dalam penelitian ini adalah aromaterapi jeruk lemon menggunakan tisu yang telah diberi 3 tetes jeruk lemon dan dihirup selama 5 menit dan diulang dua kali sehari selama 7 hari Hasil penelitian menemukan bahwa rata-rata tingkat morning sickness pada pretest sebesar 9,57 sedangkan setelah dilakukan intervensi menurun menjadi 6,40 . Selain itu, hasil statistik yang diperoleh adalah $\mathrm{p}=0,000$. Dapat disimpulkan bahwa pemberian aromaterapi jeruk lemon dapat mempengaruhi pasien emesis gravidarum.

Artikel Penelitian yang diteliti oleh (Maghfirah et al., 2020) yang berjudul "The Effectiveness of Acupressure Therapy and Aromatherapy of Lemon on the Ability of Coping and Emesis Gravidarum in Trimester

I Pregnant Women at Langsa City Community Health Centre, Aceh, Indonesia". Penelitian ini menggunakan desain penelitian eksperimen semu. Desain yang digunakan adalah non-randomized pretest-posttest control group design. Populasi dalam penelitian ini yaitu seluruh ibu hamil trimester pertama dengan keluhan mual dan muntah. Sampel diambil sebanyak 60 orang dengan menggunakan teknik purposive sampling. Responden dibagi menjadi tiga kelompok, yaitu kelompok pertama akupresur, kelompok kedua akupresur+aromaterapi lemon dan kelompok ketiga kontrol. Analisis data menggunakan analisis univariat, dan analisis bivariabel menggunakan uji-t berpasangan, uji-t dependen dan ANOVA satu arah, analisis multi-variabel menggunakan uji multikovarian, dan ANOVA. Hasil penelitian ini menunjukkan bahwa akupresur dan akupresur + terapi lemon efektif dalam mengurangi rasa mual yang dialami ibu hamil. Akupresur lemon + terapi aromaterapi secara signifikan mengurangi mual pada ibu hamil dengan $\mathrm{p}=$ $0,0001(p<0,05)$. Hasil uji t berpasangan mual dan muntah pada kelompok akupresur dan akupresur+aromaterapi lemon menurunkan jumlah mual dengan penurunan masingmasing sebesar 4,2 dan 4,85. Durasi mual juga menurun yaitu sebesar 1,55 dan 4,3 dengan $p=0,0001(p<0,05)$. Hasil uji ANOVA pada kelompok perlakuan terhadap kemampuan kopping menunjukan bahwa kelompok akupresur + aromaterapi lemon meningkatkan kemampuan koping ibu hamil sebesar 5,7 dibandingkan dengan kelompok kontrol. Kesimpulan ada pengaruh aroma terapi lemon terhadap intensitas mual muntah pada ibu hamil di wilayah kerja Puskesmas Kota Langsa dengan $p<0,05$.

Artikel Penelitian yang diteliti oleh (Purwandari et al., 2019) yang berjudul "Lemon Suangi (Citrus limon) Aromatherapy to Reduce Vomitting on" termasuk dalam kategori mual muntah ringan, 53\% atau sebanyak 8 dari 15 responden dan sisanya 47\% atau 7 Early First Trimester Pregnancy at Teling Public Health Center Wanea District Manado City". Penelitian ini menggunakan metode penelitian Quasi Experiment with One Group Pre-test and Post-test design. Populasi dan sampel seluruh ibu hamil periode Januari hingga Februari 2019 adalah 15 ibu hamil di Puskesmas Teling Atas Sektor Wanea, Manado. Analisis bivariat dalam penelitian ini menggunakan uji 
T. Frekuensi mual muntah pada ibu hamil trimester I sebelum dilakukan intervensi responden pada kategori sedang. mual, dengan frekuensi rata-rata mual muntah sebelum intervensi adalah 3,80 dengan standar deviasi 0,862, Sedangkan frekuensi mual dan muntah setelah intervensi sebagian besar pada kategori mual ringan, dengan $80 \%$ atau 12 dari 15 responden dan sisanya $20 \%$ atau 3 dari 15 responden termasuk dalam kategori mual muntah sedang dengan frekuensi sedang dengan frekuensi sedang. mual muntah 2,67 dan standar deviasi 0,900 sehingga selisih frekuensi mual muntah sebelum dan sesudah intervensi sebesar 1,13. Terdapat perbedaan frekuensi mual dan muntah pada ibu hamil trimester I setelah diberikan intervensi, yang artinya ada pengaruh pemeberian aromaterapi lemon untuk mengurangi mual muntah pada ibu hamil.

Artikel Penelitian yang diteliti oleh (Oktavia et al., 2018) yang berjudul "The Effect of Lemon Tea Aromatheraphy on Emesis Gravidarum Reduction in Primigravida Trimester I'. Penelitian ini menggunakan penelitian pra eksperimental dengan rancangan penelitian one group pretest- posttest. Populasi pada penelitian ini yaitu primigravida pada trimester pertama dengan jumlah sampel 16, teknik pengambilan sampel menggunkan purposive sampling. Hasil penelitian yaitu rata-rata skor emesis gravidarum sebelum pengobatan yaitu 4 dan setelah pengobatan 1 , artinya ada pengaruh aromaterapi lemon untuk mengurangi mual muntah pada ibu hamil trimester I.

Setelah menjalani sederhana berpasangan didapatkan selisih rata-rata sebelum dan sesudah perlakuan adalah 3. Ho ditolak dengan $\mathrm{p}$-value $=0,000<0,05$ artinya ada pengaruh aromaterapi lemon tea dalam mengurangi emesis gravidarum pada trimester pertama primigravida. Kesimpulan dari penelitian ini adalah ada pengaruh dari aromaterapi lemon tea untuk mengurangi emesis gravidarum di trimester pertama primigravida.

Artikel Penelitian yang diteliti oleh (Maternity, 2017) yang berjudul "Inhalasi Lemon Mengurangi Mual Muntah pada Ibu Hamil Trimester Satu". Penelitian ini menggunakan pendekatan pre-experimental design dengan bentuk one group pre-test and post-test. Populasi dalam penelitian ini adalah ibu hamil Trimester I yang mengalami morning sickness sebanyak 56 ibu hamil. Sampel yang digunakan pada penelitian ini yaitu sebanyak 15 ibu hamil. Teknik Sampel yang digunakan untuk pengambilan sampel yaitu dengan purposive sampling. Analisa bivariat menggunakan uji $\mathrm{t}$ dependen. Dari hasil penelitian didapatkan frekuensi mual muntah sebelum diberikan inhalasi aromaterapi lemon diperoleh nilai rata-rata 24.67 dan frekuensi mual muntah sesudah diberikan inhalasi aromaterapi lemon diperoleh rata-rata 17.87 . Kesimpulannya yaitu ada pengaruh pemberian inhalasi aromaterapi lemon terhadap morning sickness pada ibu hamil dengan P-value $=0.000$.

Artikel Penelitian yang diteliti oleh (Rofi'ah et al., 2019) yang berjudul "Efektivitas Aromaterapi Lemon untuk Mengatasi Emesis Gravidarum". Penelitian ini yaitu eksperimen semu berupa pretestpostest with control group design. Pengambilan sampel dengan total sampling 46 pasien yang dibagi menjadi 3 kelompok yaitu $0,1 \mathrm{ml} / 0,2 \mathrm{ml} / 0,3 \mathrm{ml}$ intervensi aromaterapi. Pengolahan data menggunakan uji ANOVA. Hasil penelitian menyatakan bahwa aromaterapi lemon khususnya dosis 0.2 dan 0.3 cukup efektif dalam mengatasi emesis gravidarum.

Artikel Penelitian yang diteliti oleh (Cholifah \& Nuriyanah, 2019) yang berjudul "Aromaterapi Lemon Menurunkan Mual Muntah pada Ibu Hamil Trimester I". Penelitian ini menggunakan metode pre eksperimental dengan desain one group pre- 
post test design. Teknikyang digunakan untuk pengambilan sampel yaitu teknik consecutive sampling yang memenuhi kriteria inklusi didapatkan 36 responden. Data dianalisis dengan menggunakan Wilcoxon Sign Rank Test dengan $\alpha=0,05$. Hasil Penelitian menunjukkan bahwa skala mual muntah ibu hamil trimester I sebelum pemberian aromaterapi Mean+ SD 23,33+ 3,913 sedangkan setelah pemberian aromaterapi Mean+ SD 13,67 + 4.071. Hasil wilcoxon sign rank test dengan tingkat kemaknaan $\alpha=$ 0,05 didapatkan $\mathrm{p}=0,0001(\mathrm{P}<\alpha 0,05)$ maka H1 diterima dan H0 ditolak. Simpulan hasil penelitian menunjukkan bahwa aromaterapi lemon secara bermakna mempunyai pengaruh dalam menurunkan mual muntah pada ibu hamil trimester I.

\section{Kesimpulan}

Berdasarkan analisa yang telah dilakukan oleh penulis, dapat disimpulkan bahwa penggunaan aromaterapi lemon efektif untuk mengurangi mual muntah pada kehamilan (emesis gravidarum). Saran yang dapat diberikan untuk pelaksanaan literature review selanjutnya adalah sebaiknya database yang digunakan lebih banyak sehingga bisa mendapatkan artikel yang lebih banyak dan baik.

\section{BIBLIOGRAFI}

Carolin, B. T., Syamsiah, S., \& Yuniati, R. (2020). The Effect Of Citrus Lemon Aromatherapy On Emesis Gravidarum Patient. Strada Jurnal Ilmiah Kesehatan, 9(2), 599-604. Google Scholar

Cholifah, S., \& Nuriyanah, T. E. (2019). Aromaterapi Lemon Menurunkan Mual Muntah Pada Ibu Hamil Trimester I. Jurnal Kebidanan Midwiferia, 4(1), 3643. Google Scholar

Maesaroh, S., \& Putri, M. (2019). Inhalasi Aromaterapi Lemon Menurunkan
Frekuensi Mual Muntah Pada Ibu Hamil. Jurnal Kesehatan Metro Sai Wawai, 12(1), 30-35. Google Scholar

Maghfirah, A., Ilmi, M. M., Fajar, A. T. N., \& Kadja, G. T. M. (2020). A Review On The Green Synthesis Of Hierarchically Porous Zeolite. Materials Today Chemistry, 17, 100348. Google Scholar

Manuaba, I. A. C. (2010). I Bagus, Dan Ib Gde. 2010. Ilmu Kebidanan, Penyakit Kandungan Dan Kb Untuk Pendidikan Bidan. Edisi Kedua. Jakarta: Egc. Google Scholar

Maternity, D. (2017). Inhalasi Lemon Mengurangi Mual Muntah Pada Ibu Hamil Trimester Satu. Jurnal Ilmiah Bidan, 2(3), 10-15. Google Scholar

Medforth, J., Battersby, S., Evans, M., Marsh, B., \& Walker, A. (2013). Kebidanan Oxford Dari Bidan Untuk Bidan. Jakarta: Egc. Google Scholar

Mulyono, E., Sumangat, D., \& Hidayat, T. (2018). Peningkatan Mutu Dan Efisiensi Produksi Minyak Akar Wangi Melalui Teknologi Penyulingan Dengan Tekanan Uap Bertahap. Google Scholar

Namazi, M., Akbari, S. A. A., Mojab, F., Talebi, A., Majd, H. A., \& Jannesari, S. (2014). Aromatherapy With Citrus Aurantium Oil And Anxiety During The First Stage Of Labor. Iranian Red Crescent Medical Journal, 16(6). Google Scholar

Oktavia, N. S., Susanti, D., \& Anggalia, R. (2018). The Effect Of Lemon Tea Aromatherapy On Emesis Gravidarum Reduction In Primigravida Trimester I. Jurnal Kesehatan Ibu Dan Anak, 12(2), 145-152. Google Scholar

Purwandari, A., Tuju, S., Lumy, F., \& Anisa, W. (2019). Lemon Suangi (Citrus Limon) Aromatherapy To Reduce Vomitting On Early First Trimester Pregnancy At Teling Public Health Center Wanea District Manado City. 
Parity, 30(1), 6. Google Scholar

Rinata, E., \& Ardillah, F. R. (2017). Penanganan Emesis Gravidarum Pada Ibu Hamil Di Bpm Nunik Kustantinna Tulangan-Sidoarjo. Google Scholar

Rofi'ah, S., Widatiningsih, S., \& Sukini, T. (2019). Efektivitas Aromaterapi Lemon Untuk Mengatasi Emesis Gravidarum. Jurnal Kebidanan, 9(1), 9-16. Google Scholar

Runiari, N. (2010). Asuhan Keperawatan Pada Klien Dengan Hiperemesis Gravidarum: Penerapan Konsep Dan Teori Keperawatan. Jakarta: Salemba Medika. Google Scholar
Safajou, F., Shahnazi, M., \& Nazemiyeh, H. (2014). The Effect Of Lemon Inhalation Aromatherapy On Nausea And Vomiting Of Pregnancy: A DoubleBlinded, Randomized, Controlled Clinical Trial. Iranian Red Crescent Medical Journal, 16(3). Google Scholar

Vitrianingsih, V., \& Khadijah, S. (2019). Efektivitas Aroma Terapi Lemon Untuk Menangani Emesis Gravidarum. Jurnal Keperawatan, 11(4), 277-284. Google Scholar

Young, G. (2011). Essencial Oil Pocket Reference 5 Th Ed. Amazon: Life Science Pubhlising. Google Scholar

\section{Copyright holder:}

Is Susiloningtyas dan Siti Suhartinah (2021)

First publication right:

Jurnal Health Sains

This article is licensed under: 